\title{
Surveillance for leptospirosis in the Americas, 1996-2005: a review of data from ministries of health
}

\author{
Federico Costa, ${ }^{1}$ Martha Silvia Martinez-Silveira, ${ }^{1}$ José E. Hagan, ${ }^{2}$ \\ Rudy A. Hartskeerl, ${ }^{3}$ Mitermayer Galvão dos Reis, ${ }^{1}$ and Albert Icksang $\mathrm{Ko}^{2}$
}

Suggested citation Costa F, Martinez-Silveira MS, Hagan JE, Hartskeerl RA, Reis MG, and Ko AI. Surveillance for leptospirosis in the Americas, 1996-2005: a review of data from ministries of health. Rev Panam Salud Publica. 2012;32(3):169-77.

ABSTRACT Objective. To characterize current leptospirosis reporting practices in the Americas.

Methods. Information was collected from the official websites of national ministries of health from the Americas region and two international organizations; personal communications; and three international morbidity databases. For all sources other than the morbidity databases, the review was limited to official reports citing clinically suspected and laboratory confirmed leptospirosis cases or deaths during the period 1996-2005.

Results. A total of 73 out of 1644 reports met the selection criteria and were included in the analysis. Published leptospirosis data were available from half of the countries/sovereign territories (24 out of 48), and 18 of them had mandatory notification policies for leptospirosis. The sum of the median number of leptospirosis cases notified annually by the 24 countries/ territories was 4 713.5, but just three countries (Brazil, Costa Rica, and Cuba) accounted for $83.1 \%$ (3 920 cases) of the notifications. Eight (16.7\%) countries reported deaths due to leptospirosis. The sum of the median number of deaths reported annually for the eight countries was 380, but 349 (91.8\%) were reported by Brazil.

Conclusions. Notification practices in the Americas for leptospirosis are limited. Therefore, the numbers of cases and deaths reported are not representative for the region. The lack of leptospirosis data for many countries/territories may reflect weaknesses in certain aspects of national surveillance systems, including mandatory reporting policies, clinical laboratory infrastructure for performing case confirmation, and capacity to collect reported cases. Improved surveillance of leptospirosis cases and deaths in the Americas is needed to allow monitoring of regional epidemiological patterns and to estimate the burden of this important disease.

Key words Leptospirosis; epidemiologic surveillance; disease notification; review; Americas.

Laboratório de Patologia e Biologia Molecular (LPBM), Centro de Pesquisas Gonçalo Moniz (CPqGM), Fundação Oswaldo Cruz (Fiocruz), Ministério da Saúde, Salvador, Brazil. Send correspondence to: Federico Costa, fcosta2001@gmail.com

2 Laboratory of Epidemiology and Public Health (LEPH), Division of Epidemiology of Microbial Diseases, School of Public Health, Yale University, New Haven, Connecticut, United States of America.

3 WHO/FAO/OIE and National Collaborating Centre for Reference and Research on Leptospirosis, Department of Biomedical Research, Royal Tropical Institute (KIT), Amsterdam, The Netherlands.
Leptospirosis is a globally important zoonotic disease caused by pathogenic spirochetes of the genus Leptospira (1). Leptospires have been serologically classified based on antigenic determinants into more than 230 serovars. More recent studies based on DNA relatedness have classified Leptospira into at least 17 species (1-4). L. interrogans can infect both wild and domestic animals. The most common sources for human infection in the Americas are rodents, dogs, livestock, and wild mammals (5). Indirect contact with infected animals, via water or soil contaminated with infected urine, is a more common source for human infection than direct contact with infected animals $(6,7)$. Leptospires can survive for weeks or months in the environment under favorable conditions, such as tem- 
peratures of $28^{\circ} \mathrm{C}$ to $32^{\circ} \mathrm{C}$ and a neutral or slightly alkaline $\mathrm{pH}(8)$. Severe disease causes multisystem complications such as acute renal failure and pulmonary hemorrhage, and the overall case fatality varies from $5 \%$ to $15 \%(6,8)$.

Global incidence of leptospirosis is still not well known (9), but estimates indicate approximately 320000 annual cases of leptospirosis worldwide (10, 11). There are no estimates of the annual number of leptospirosis cases for the Americas region overall. National ministries of health (MoHs) are the most common source of data for generating regional estimates for leptospirosis and other diseases $(5,12)$. The surveillance systems for each country/territory cover large and heterogeneous geographic areas. The effectiveness of surveillance is often limited by weaknesses in various aspects of the system, including mandatory reporting policies, clinical laboratory infrastructure for performing case confirmation, and surveillance mechanisms for collecting reported cases. Additional challenges in the case of leptospirosis include 1) difficulties in recognizing the disease due to its often undifferentiated clinical presentation, and 2) the challenging technical requirements of its laboratory confirmation (13).

Despite their limitations, national surveillance systems provide useful data about leptospirosis incidence trends, aid in outbreak identification, and support government interventions. However, the Americas region is particularly challenging in terms of leptospirosis epidemiology due to the wide diversity of environmental, socioeconomic, and cultural conditions. Within this context, reviewing surveillance systems and case notification practices used in different countries / territories in the Americas can help 1) identify information deficits and inconsistent data within sub-regions, and 2) define strategies for better measurements of the burden of disease. The aim of this study was to characterize data on leptospirosis incidence and mortality in the Americas collected and reported by MoHs and international morbidity databases.

\section{MATERIALS AND METHODS}

\section{Search strategy}

Two different search strategies were used to locate leptospirosis surveillance data for the Americas region: 1) review of national $\mathrm{MoH}$ and international organization websites, and 2) review of international morbidity databases.

Review of $\mathrm{MoH} /$ international organization websites. From 15 to 31 August 2007, an Internet search was conducted using the key words "Ministry of Health" and "[country/sovereign territory name]" to identify the official $\mathrm{MoH}$ website for each country/territory in the Americas. For territories, the $\mathrm{MoH}$ website of either the territory or the mother country was used. When available, the "search" function of the official $\mathrm{MoH}$ websites was used to locate published surveillance information by searching on the key words "surveillance," "epidemiological service," "statistics," and "publications," and selecting all bulletins and reports on notifiable diseases published from 1 January 1996 to 31 December 2005. An additional search was then conducted on the key words "Leptospira" and "leptospirosis." The websites of the Pan American Health Organization (PAHO) (www.paho.org) and the Caribbean Epidemiology Centre (CAREC) (www.carec.net) were also searched to locate information on leptospirosis provided by $\mathrm{MoH}$ in the Americas region. Finally, the $\mathrm{MoH}$ of each country/territory in the region was contacted via e-mail and asked for information on leptospirosis suspected cases, confirmed cases, and deaths. In their e-mail, the authors also asked if leptospirosis was a disease of mandatory notification. All bulletins and reports published within the 1 January 1996 to 31 December 2005 time frame were downloaded and stored in folders by country/territory.

Review of international morbidity databases. The authors located and obtained three major databases for leptospirosis: the World Organisation for Animal Health (Office International des Epizooties, OIE, www.oie.int) database; the CAREC database (provided by E. Boisson); and LeptoNet (www.leptonet.net).

\section{Selection criteria}

Bulletins and reports from the websites of MoHs and international organizations were reviewed and included in the study if they met all of the following criteria: 1) reported clinically suspected or laboratory-confirmed leptospirosis cases or deaths, 2) reported information stratified by year, and 3) reported informa- tion for the entire unit of geographical evaluation (country/sovereign territory). The following reports/bulletins were excluded from the analysis: 1) those that only covered non-human animals (e.g., wildlife); 2) those on general leptospirosis issues, such as diagnostic methodologies or genomic, microbiologic, or molecular techniques; and 3) those with duplicated information from the same source. The inclusion and exclusion criteria were not applied to the material from the international morbidity databases.

\section{Data extraction and descriptive analysis}

Data about the data source (organization/institution), country/territory, study period, and number of clinically suspected and laboratory-confirmed leptospirosis cases and deaths were extracted and entered into an Excel database. For each country/territory in the Americas, a summary statistic was calculated for annual median number of cases and deaths. Median number of cases and deaths were then summed to obtain subregional and regional total number of cases. Case fatality was estimated when information on cases and deaths, reported by the $\mathrm{MoH}$, was available. Population data were based on calculations for the year 2000 from the United Nations Population Division (http:/ / esa.un. org/unpd/wpp/Excel-Data/population. htm). Pearson correlation coefficients were used as measures of the strength of the linear relationship between numbers of cases from two different surveillance systems. Correlation analyses were performed using Epi Info ${ }^{\mathrm{TM}}$ for Windows software (Centers for Disease Control and Prevention, Atlanta, GA, USA).

\section{RESULTS}

The above-mentioned search strategies identified 1644 reports published during the 10-year period between 1 January 1996 and 31 December 2005. Of those 1644 reports, $1350(82.1 \%)$ were obtained from $\mathrm{MoH}$ websites, $257(15.6 \%)$ from the PAHO website, $32(1.9 \%)$ from the CAREC website, $5(<1.0 \%)$ from personal communication, and $2(<1.0 \%)$ from the international morbidity databases (one each from the OIE database and LeptoNet). Other than the data obtained from the morbidity databases, all information retrieved for review was evaluated ac- 
TABLE 1. Median annual number of confirmed leptospirosis cases reported by Ministry of Health official websites, first year of mandatory reporting, period of available information, and data source, by country/territory, Americas region, 1996-2005

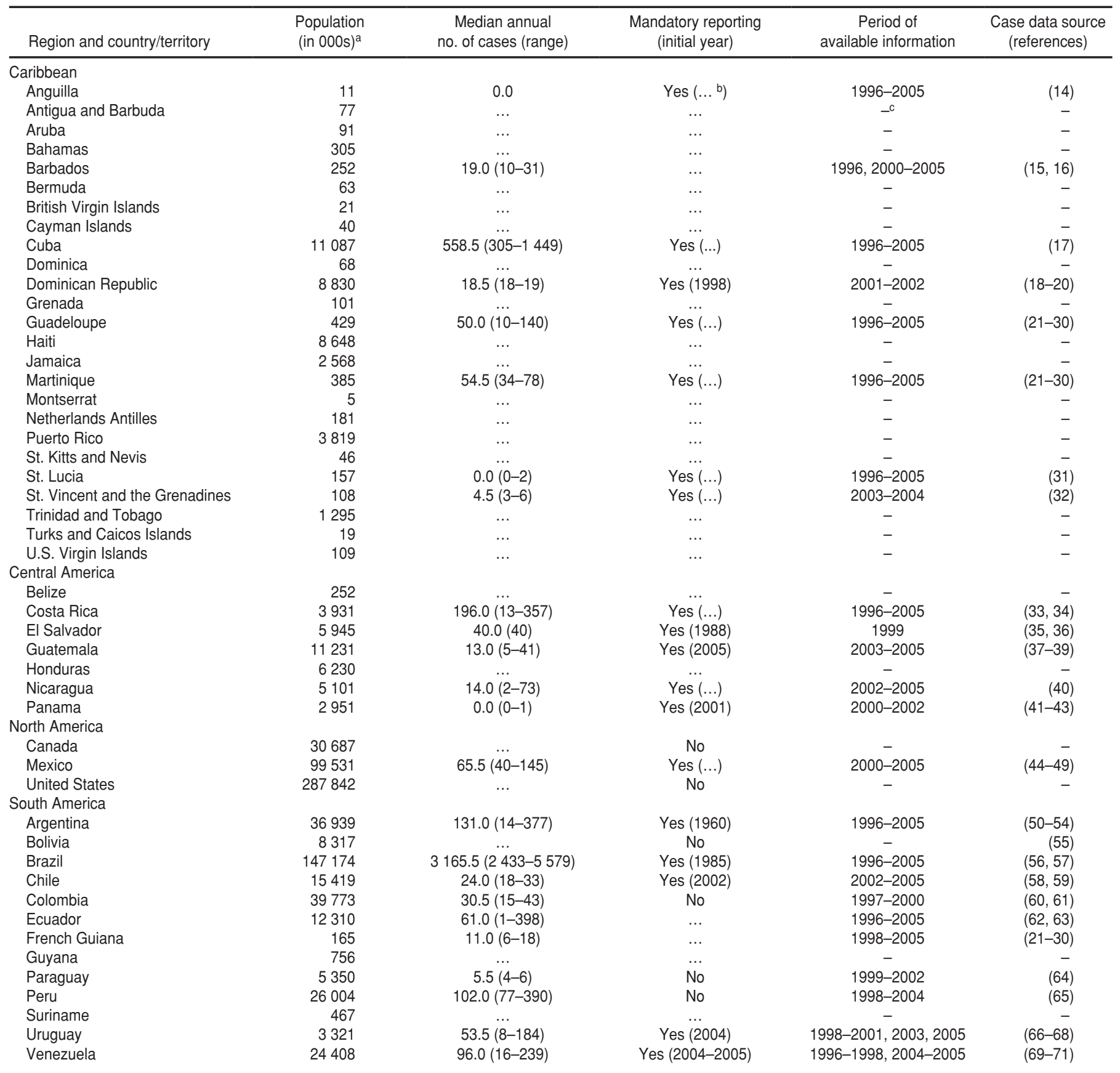

a Data obtained from United Nations (http://esa.un.org/unpd/wpp/Excel-Data/population.htm).

${ }^{b}$ Data not available.

${ }^{\mathrm{c}}$ Not applicable.

cording to the above-mentioned inclusion criteria. A total of 73 reports $(4.4 \%)$ met the inclusion criteria and were considered in the study.

Half of the countries/territories in the Americas (24 out of 48) reported confirmed leptospirosis cases for at least one year during the study period (Table 1).
Clinically suspected cases were reported by only seven countries (14.6\%) and were not included in further analysis. There was no observed increase in the number of countries/territories reporting leptospirosis during the study period, and only $11(45.8 \%)$ of the 24 countries/territories with available information reported cases during the period 2001-2005. Only $18(75.0 \%)$ of the 24 countries/territories that had available information for the study period had confirmed mandatory notification policies. In South America, 10 of $13(76.9 \%)$ countries/territories reported information on leptospirosis. Data were not found for Bolivia, Guyana, or 
Suriname. Of the 10 South American countries/territories reporting data, three of them (Argentina, Brazil, and Ecuador) reported leptospirosis cases regularly every year from 1996 to 2005. Five South American countries had confirmed mandatory notification for leptospirosis (Argentina, Brazil, Chile, Uruguay, and Venezuela). In Central America, 5 out of the $7(71.4 \%)$ countries had available information. Within that sub-region, Costa Rica was the only country that reported leptospirosis regularly from 1996 to 2005, and one of five (along with El Salvador, Guatemala, Nicaragua, and Panama) with confirmed mandatory notification for the disease. In the Caribbean, only 8 out of the 25 countries/territories (32.0\%) reported data on leptospirosis (Anguilla, Barbados, Cuba, Dominican Republic, Guadeloupe, Martinique, St. Lucia, and St. Vincent and the Grenadines). Of those eight countries/territories, all but Barbados had confirmed mandatory notification policies, but only Anguilla, Cuba, Guadeloupe, and Martinique reported leptospirosis cases for the entire study period (1996-2005). Mexico was the only country in North America that reported data during the study period (providing information for the years 2000-2005) and the only one in the sub-region with mandatory notification for the disease.

The total median number of leptospirosis cases reported annually by $\mathrm{MoHs}$ in the Americas during the study period was 4713.5. South America reported an annual median of 3680 cases $(78.1 \%$ of the total number of cases for the region), followed by the Caribbean, which reported 705 cases (14.9\% of the regional total). In Central America, an annual median of 263 cases was reported. The North American countries (among which Mexico was the only one reporting cases) reported 65.5 cases (1.4\% of the regional total). Reporting varied widely between countries/territories within sub-regions. For example, Brazil reported 3165.5 cases or $86 \%$ of all cases reported for South America (a total of 3 680). In Central America, Costa Rica was responsible for 196 out of 263 cases or $74.5 \%$ of all notifications for the sub-region. Cuba reported 558.5 out of 705 cases or $79.2 \%$ of all cases reported by the Caribbean sub-region.

Information from the national $\mathrm{MoHs}$ was compared with data from the international institutions and the morbidity databases (Table 2). OIE reported lepto-
TABLE 2. Median annual number of confirmed leptospirosis cases, notification source, number of years with available data, and data source, by country/territory, Americas region, 1996-2005

\begin{tabular}{|c|c|c|c|c|}
\hline $\begin{array}{l}\text { Region and } \\
\text { country/territory }\end{array}$ & $\begin{array}{l}\text { Median annual no. } \\
\text { of cases (range) }\end{array}$ & $\begin{array}{l}\text { Notification } \\
\text { source }\end{array}$ & $\begin{array}{l}\text { No. of years with } \\
\text { available data }\end{array}$ & $\begin{array}{l}\text { Data source } \\
\text { (references) }\end{array}$ \\
\hline \multicolumn{5}{|l|}{ Caribbean } \\
\hline \multirow[t]{2}{*}{ Anguilla } & 0.0 & $\mathrm{MoH}^{\mathrm{a}}$ & 10 & (14) \\
\hline & 0.0 & CAREC ${ }^{b}$ & 1 & (72) \\
\hline Antigua and Barbuda & 0.0 & $\mathrm{OIE}^{\mathrm{c}}$ & 3 & (73) \\
\hline Aruba & $\ldots{ }^{d}$ & $-^{\mathrm{e}}$ & - & - \\
\hline \multirow[t]{2}{*}{ Bahamas } & $0.0(0-4)$ & OIE & 5 & (73) \\
\hline & 0.0 & CAREC & 1 & (72) \\
\hline \multirow[t]{4}{*}{ Barbados } & $19.0(10-31)$ & $\mathrm{MoH}$ & 6 & $(15,16)$ \\
\hline & $28.0(23-28)$ & OIE & 3 & (73) \\
\hline & $31.0(31)$ & $\mathrm{PAHO}^{\dagger}$ & 1 & (74) \\
\hline & 0.0 & CAREC & 1 & (72) \\
\hline \multirow[t]{2}{*}{ Bermuda } & 0.0 & OIE & 2 & (73) \\
\hline & 0.0 & CAREC & 1 & (72) \\
\hline \multirow[t]{2}{*}{ British Virgin Islands } & $0.5(0-1)$ & OIE & 2 & (73) \\
\hline & 0.0 & CAREC & 1 & (72) \\
\hline Cayman Islands & 0.0 & CAREC & 1 & (72) \\
\hline \multirow[t]{2}{*}{ Cuba } & 558.5 (305-1 449) & $\mathrm{MoH}$ & 10 & (17) \\
\hline & 553.0 (281-1 442) & OIE & 9 & (73) \\
\hline \multirow[t]{2}{*}{ Dominica } & 0.0 & OIE & 2 & (73) \\
\hline & 0.0 & CAREC & 1 & (72) \\
\hline \multirow[t]{3}{*}{ Dominican Republic } & $18.5(18-19)$ & $\mathrm{MoH}$ & 2 & $(18,19)$ \\
\hline & $239.0(239)$ & PAHO & 1 & $(75)$ \\
\hline & $37.0(10-114)$ & OIE & 9 & (73) \\
\hline \multirow[t]{2}{*}{ Grenada } & $8.0(8)$ & OIE & 1 & (73) \\
\hline & 0.0 & CAREC & 1 & (72) \\
\hline \multirow[t]{2}{*}{ Guadeloupe } & $50.0(10-140)$ & $\mathrm{MoH}$ & 10 & $(21-30)$ \\
\hline & $68.5(0-141)$ & OIE & 8 & (73) \\
\hline Haiti & 0.0 & OIE & 1 & (73) \\
\hline \multirow{2}{*}{ Jamaica } & 404.5 (124-693) & OIE & 4 & (73) \\
\hline & 0.0 & CAREC & 1 & (72) \\
\hline \multirow[t]{2}{*}{ Martinique } & 54.5 (34-78) & $\mathrm{MoH}$ & 10 & $(21-30)$ \\
\hline & 0.0 & OIE & 1 & (73) \\
\hline Montserrat & 0.0 & CAREC & 1 & (72) \\
\hline Netherland Antilles & 0.0 & OIE & 1 & (73) \\
\hline Puerto Rico & & - & - & - \\
\hline \multirow[t]{2}{*}{ St. Kitts and Nevis } & 0.0 & OIE & 4 & (73) \\
\hline & 0.0 & CAREC & 1 & (72) \\
\hline St. Lucia & $0.0(0-2)$ & $\mathrm{MoH}$ & 8 & \\
\hline & $1.0(1)$ & CAREC & 1 & (72) \\
\hline St. Vincent and the & & & & \\
\hline Grenadines & $4.5(3-6)$ & $\mathrm{MoH}$ & 2 & (32) \\
\hline & $10.0(2-11)$ & OIE & 3 & (73) \\
\hline Trinidad and Tobago & $35.0(0-156)$ & OIE & 3 & \\
\hline Turks and Caicos & & & & \\
\hline Islands & $\ldots$ & - & - & - \\
\hline U.S. Virgin Islands & $\ldots$ & - & - & - \\
\hline Central America & & & & \\
\hline Belize & $0.3(0-1)$ & OIE & 7 & (73) \\
\hline & 0.0 & CAREC & 1 & (72) \\
\hline Costa Rica & $196.0(8-300)$ & $\mathrm{MoH}$ & 9 & (33) \\
\hline & $197.0(0-270)$ & OIE & 5 & (73) \\
\hline El Salvador & $40.0(6-85)$ & $\mathrm{MoH}$ & 4 & (35) \\
\hline & $20.0(0-240)$ & OIE & 6 & (73) \\
\hline Guatemala & $13.0(5-41)$ & $\mathrm{MoH}$ & 3 & $(37-39 ; 76)$ \\
\hline & $2.5(0-14)$ & OIE & 4 & (73) \\
\hline Honduras & $22.0(17-39)$ & OIE & 3 & (73) \\
\hline Nicaragua & $14.0(0-73)$ & $\mathrm{MoH}$ & 8 & (40) \\
\hline & $32.0(0-67)$ & OIE & 4 & (73) \\
\hline Panama & $0.0(0-1)$ & $\mathrm{MoH}$ & 3 & $(41-43)$ \\
\hline & $0.0(0-4)$ & OIE & 8 & (73) \\
\hline & $1.0(0-6)$ & LepNg & 8 & (77) \\
\hline North America & & & & \\
\hline Canada & 0.0 & OIE & 1 & (73) \\
\hline & $0.0(0-3)$ & LepN & 3 & (77) \\
\hline & & & & (con \\
\hline
\end{tabular}


TABLE 2. Continued

\begin{tabular}{|c|c|c|c|c|}
\hline $\begin{array}{c}\text { Region and } \\
\text { country/territory }\end{array}$ & $\begin{array}{l}\text { Median annual no. } \\
\text { of cases (range) }\end{array}$ & $\begin{array}{l}\text { Notification } \\
\text { source }\end{array}$ & $\begin{array}{l}\text { No. of years with } \\
\text { available data }\end{array}$ & $\begin{array}{l}\text { Data source } \\
\text { (references) }\end{array}$ \\
\hline \multirow[t]{3}{*}{ Mexico } & $65.5(40-145)$ & $\mathrm{MoH}$ & 6 & $(44-49)$ \\
\hline & $40.0(0-76)$ & OIE & 7 & (73) \\
\hline & 269.0 (264-789) & LepN & 3 & (77) \\
\hline \multirow[t]{2}{*}{ United States } & $13.0(0-58)$ & OIE & 9 & (73) \\
\hline & $48.0(45-58)$ & LepN & 3 & (77) \\
\hline \multicolumn{5}{|l|}{ South America } \\
\hline \multirow[t]{2}{*}{ Argentina } & $177.0(30-377)$ & $\mathrm{MoH}$ & 10 & $(50-53)$ \\
\hline & $142.5(7-376)$ & OIE & 5 & (73) \\
\hline Bolivia & 0.0 & OIE & 3 & (73) \\
\hline \multirow[t]{3}{*}{ Brazil } & $\begin{array}{c}3038.5(2433- \\
3638)\end{array}$ & $\mathrm{MoH}$ & 8 & (56) \\
\hline & $\begin{array}{c}2218.0(2042- \\
2394)\end{array}$ & OIE & 2 & (73) \\
\hline & $840.0(694-882)$ & LepN & 3 & (73) \\
\hline \multirow[t]{3}{*}{ Chile } & $24.5(18-33)$ & $\mathrm{MoH}$ & 4 & (77) \\
\hline & 24.0 (18-33) & OIE & 7 & (58) \\
\hline & $5.0(5-6)$ & LepN & 8 & (73) \\
\hline \multirow{2}{*}{ Colombia } & $30.5(15-43)$ & $\mathrm{MoH}$ & 4 & (61) \\
\hline & $43.5(12-162)$ & OIE & 5 & (73) \\
\hline \multirow[t]{2}{*}{ Ecuador } & $61.0(1-398)$ & $\mathrm{MoH}$ & 10 & (62) \\
\hline & $29.0(0-328)$ & OIE & 7 & (73) \\
\hline \multirow[t]{2}{*}{ French Guiana } & $11.0(6-18)$ & $\mathrm{MoH}$ & 8 & (73) \\
\hline & 0.0 & OIE & 4 & $(21-28)$ \\
\hline \multirow[t]{3}{*}{ Guyana } & $15.0(15)$ & $\mathrm{MoH}$ & 1 & (78) \\
\hline & $73.0(73)$ & OIE & 1 & (73) \\
\hline & $48.0(0-96)$ & CAREC & 1 & (72) \\
\hline \multirow[t]{2}{*}{ Paraguay } & $5.5(4-6)$ & $\mathrm{MoH}$ & 4 & (64) \\
\hline & $5.0(3-12)$ & OIE & 5 & (73) \\
\hline \multirow[t]{2}{*}{ Peru } & $102.0(77-390)$ & $\mathrm{MoH}$ & 7 & (65) \\
\hline & $18.0(0-54)$ & OIE & 4 & (73) \\
\hline \multirow[t]{2}{*}{ Suriname } & $159.0(159)$ & OIE & 1 & (73) \\
\hline & $8.0(8)$ & CAREC & 1 & $(79,80)$ \\
\hline \multirow[t]{3}{*}{ Uruguay } & $53.5(8-184)$ & $\mathrm{MoH}$ & 6 & $(66-68)$ \\
\hline & $135.5(45-233)$ & OIE & 4 & $(73)$ \\
\hline & $24.0(21-51)$ & LepN & 3 & (77) \\
\hline \multirow{2}{*}{ Venezuela } & $96.0(16-239)$ & $\mathrm{MoH}$ & 5 & $(69-71)$ \\
\hline & $97.0(27-214)$ & OIE & 6 & (73) \\
\hline
\end{tabular}

a MoH: Ministry of Health.

b CAREC: Caribbean Epidemiology Centre.

c OIE: World Organisation for Animal Health (http://web.oie.int/hs2/report.asp?lang=en).

d Data not available.

e Not applicable.

f PAHO: Pan American Health Organization.

g LepN: LeptoNet (www.leptonet.net).

TABLE 3. Leptospirosis case fatality (median annual \% and number of deaths) reported by Ministry of Health official websites, period of available information, and data source, by country, Americas region, 1996-2005

\begin{tabular}{lcccc}
\hline $\begin{array}{c}\text { Region and } \\
\text { country }\end{array}$ & $\begin{array}{c}\text { Median annual } \\
\text { \% case fatality (range) }\end{array}$ & $\begin{array}{c}\text { Median annual } \\
\text { no. of deaths (range) }\end{array}$ & $\begin{array}{c}\text { Period of } \\
\text { available information }\end{array}$ & $\begin{array}{c}\text { Data source } \\
\text { (references) }\end{array}$ \\
\hline $\begin{array}{c}\text { Caribbean } \\
\text { Barbados }\end{array}$ & $10.0(2-50)$ & $2.0(0-19)$ & $1996,2000-2005$ & $(15,16)$ \\
Central America & $2.1(2-5)$ & $5.0(4-7)$ & $2001-2004$ & $(81)$ \\
Costa Rica & $0.0(0-3)$ & $1.0(0-4)$ & $2002-2005$ & $(82-85)$ \\
$\quad$ Nicaragua & $3.6(2-7)$ & $4.0(1-12)$ & $1996-2005$ & $(50-53,86)$ \\
South America & $12.0(7-13)$ & $349.0(280-439)$ & $1996-2005$ & $(56)$ \\
Argentina & $12.9(0-27)$ & $2.0(0-6)$ & $2002-2005$ & $(58,87)$ \\
Brazil & $6.1(0-38)$ & $5.0(0-8)$ & $1998-2001,2003$ & $(66,67)$ \\
Chile & $9.4(2-73)$ & $12.0(4-27)$ & $1996-1998,2004-2005$ & $(69-71)$ \\
Uruguay & & & & \\
Venezuela & & & & \\
\hline
\end{tabular}

spirosis cases for 40 countries/territories in the Americas, CAREC reported cases for 15 (only within the Caribbean), LeptoNet reported cases for 7 , and $\mathrm{PAHO}$ reported cases for 2. For 23 countries/ territories, information was available from both the national $\mathrm{MoHs}$ and the OIE. The total median annual number of cases reported for those 23 countries/ territories was 4648.5 and 3773.6 respectively. The median annual number of cases reported by the MoHs and the OIE showed strong positive correlation $(r=0.995)$. The MoHs and LeptoNet provided information for five countries/ territories, and the MoHs and CAREC provided information for four. The $\mathrm{MoHs}$ and PAHO provided information for two countries.

Eight countries in the Americas (16.7\% of all countries/territories in the region) reported leptospirosis deaths (Table 3 ). Five of the countries with leptospirosis death surveillance were in South America and two were in Central America. Barbados was the only Caribbean country/ territory to report deaths from the disease. The total median number of deaths per year reported for the entire region was 380 , but 349 of those $(91.8 \%)$ were reported by just one country (Brazil). The three international databases used in the study (CAREC, LeptoNet, and OIE) did not report information about leptospirosis deaths. Barbados, Brazil, and Chile reported a high median rate of annual case fatality ( $\geq 10.0 \%$ ). Uruguay and Venezuela reported a median rate of annual case fatality of $6.1 \%$ and $9.4 \%$ respectively. In Argentina, Costa Rica, and Nicaragua, the median annual case fatality was $<5 \%$.

\section{DISCUSSION}

Despite the fact that leptospirosis is considered an emerging disease (88), this study found that case surveillance data were only available for $50.0 \%$ of the countries/territories in the Americas region; confirmation of mandatory notification policies for leptospirosis was only available from 18 (37.5\%) of the countries / territories; and less than $20 \%$ of countries / territories in the region reported leptospirosis deaths. Therefore, although a number is given in this report for total median annual cases and deaths due to leptospirosis, it is not representative of the entire region due to the limited num- 
ber of countries/territories with official reporting data.

Previous estimates and evaluations of leptospirosis incidence and mortality from the global literature have been based on qualitative assessment and expert opinion $(5,10)$. A previous calculation based on official surveillance data estimated 320000 annual cases of leptospirosis globally, with the Americas contributing about $10 \%$ of the notified cases ( 2000 cases) (5). These estimates included a large number of cases from Brazil (> 28 000) (5), which was not consistent with historical reports from the Brazilian $\mathrm{MoH}$ (56). The total median annual number of deaths reported in the Americas region (380) is consistent with the number reported by the World Health Organization in 1999 (261 deaths). Case fatality reported in the region is, in general, in agreement with previous studies (89-94). The low case fatality reported in some countries (e.g., Nicaragua) suggests that there may be under-recognition or sub-notification of leptospirosis deaths.

There was substantial regional variability in reported leptospirosis cases and deaths. Regional variability is expected due to environmental heterogeneity and differences in sanitation and health care infrastructure. However, some of the observed regional variability in case reporting may be attributable to differences in surveillance methodology. The fact that $>80.0 \%$ of the cases and $>90.0 \%$ of deaths were reported by three countries/territories with a long history of national surveillance supports the hypothesis that the major source of variation was due to surveillance methodology. Substantial effort is needed to increase the geographic coverage of leptospirosis data by national $\mathrm{MoHs}$ in the Americas region. A large number of countries/territories, especially in the

1. Bharti AR, Nally JE, Ricaldi JN, Matthias MA, Diaz MM, Lovett MA, et al. Leptospirosis: a zoonotic disease of global importance. Lancet Infect Dis. 2003;3(12):757-71.

2. Brenner DJ, Kaufmann AF, Sulzer KR, Steigerwalt AG, Rogers FC, Weyant RS. Further determination of DNA relatedness between serogroups and serovars in the family Leptospiraceae with a proposal for Leptospira alexanderi sp. nov. and four new Leptospira genomospecies. Int J Syst Bacteriol. 1999; $49 \mathrm{Pt}$ 2:839-58.
Caribbean, report leptospirosis cases only through international organizations $(72,73)$. International databases such as LeptoNet and those provided by OIE and CAREC receive heterogenic information (including data from leptospirosis reference laboratories) that may only correspond to limited areas in each country/sovereign territory. It is unclear to what extent the regional data contained in these databases are representative of the entire country/territory.

\section{Limitations}

This review had some limitations that should be considered when interpreting the findings. First, most of the data used in the analysis came from websites and thus may not be replicable in future studies. For example, 16 of the 73 selected reports and bulletins analyzed in August of 2007 (21.9\%) were not available online when the authors tried to retrieve them in August 2010. (Copies of all data accessed online in 2007 were stored and are available by request.) Second, variation in clinical case definitions and laboratory confirmation methodology may be potential sources of variability between countries/territories in the Americas region. Third, because laboratory diagnosis of leptospirosis is technically challenging, national systems reporting laboratory-confirmed cases may report fewer cases than those reporting only clinically suspected cases.

\section{Recommended research}

Growing trends of rapid urbanization and changing weather patterns, particularly increased heavy rainfall and flooding, are likely to lead to more frequent severe leptospirosis epidemics (88, 95, 96). In addition, increasing globalization and international travel will continue

\section{REFERENCES}

3. Levett PN. Sequence-based typing of leptospira: epidemiology in the genomic era. PLoS Negl Trop Dis. 2007;1(2):e120.

4. Levett PN, Morey RE, Galloway RL, Steigerwalt AG. Leptospira broomii sp. nov., isolated from humans with leptospirosis. Int J Syst Evol Microbiol. 2006;56(Pt 3):671-3.

5. World Health Organization. Leptospirosis worldwide, 1999. Wkly Epidemiol Rec. 1999; 74(29):237-42. Available from: http://www. leptonet.net/assets/images/wer7429.pdf Accessed 23 October 2010. to increase the risk of imported cases of this difficult-to-diagnose and potentially fatal disease. Therefore, further research is recommended to further characterize leptospirosis. The methodology described in this report may be useful for conducting systematic reviews to help estimate the burden of this important disease.

\section{Conclusions}

Although leptospirosis is not included as a notifiable illness in the majority of countries/territories in the Americas, it has an important impact on health in many parts of the region. However, current notification practices for leptospirosis in the region are limited. Therefore, the numbers of cases and deaths reported are not representative for the region. The lack of leptospirosis data for a large proportion of countries / territories in the Americas may reflect weaknesses in certain aspects of national surveillance systems, including mandatory reporting policies, clinical laboratory infrastructure for performing case confirmation, and the capacity to collect reported cases. Improved surveillance in the region is therefore urgently needed to strengthen capacity for early outbreak identification and accurate monitoring of regional patterns, and to estimate the regional burden of disease.

Acknowledgments. The authors would like to thank E. Boisson of CAREC for providing the surveillance database used in this work. This research was supported by the Secretariat of Health Surveillance (SVS) and the Oswaldo Cruz Foundation (Fiocruz) of the Brazilian Ministry of Health, and the U.S. National Institutes of Health (grants U01 AI088752, R01 AI052473, R24 TW007988, and D43 TW00919).

6. Farr RW. Leptospirosis. Clin Infect Dis. 1995; 21(1):1-6; quiz 7-8.

7. Levett PN. Leptospirosis. Clin Microbiol Rev. 2001;14(2):296-326.

8. Faine SB, Adler B, Bolin C, Perolat P. Leptospira and leptospirosis. 2nd ed. Melbourne (Australia): MediSci; 1999.

9. World Health Organization. Zoonoses and veterinary public health. Leptospirosis Burden Epidemiology Reference Group (LERG) [Internet]. Geneva: WHO; c2010 [updated 13 July 2010]. Available from: http:/ / www.who. 
int/zoonoses/diseases/lerg/en/ Accessed 17 July 2010.

10. Pappas G, Papadimitriou P, Siozopoulou V, Christou L, Akritidis N. The globalization of leptospirosis: worldwide incidence trends. Int J Infect Dis. 2008;12(4):351-7.

11. World Health Organization; Royal Tropical Institute; International Leptospirosis Society. WHO-KIT-LeptoNet [database on the Internet]. Geneva: WHO; c2008. Available from: http://www.leptonet.net Accessed 20 October 2008 .

12. Hotez PJ, Bottazzi ME, Franco-Paredes C, Ault SK, Periago MR. The neglected tropical diseases of Latin America and the Caribbean: a review of disease burden and distribution and a roadmap for control and elimination. PLoS Negl Trop Dis. 2008;2(9):e300.

13. McBride AJ, Santos BL, Queiroz A, Santos AC, Hartskeerl RA, Reis MG, et al. Evaluation of four whole-cell Leptospira-based serological tests for diagnosis of urban leptospirosis. Clin Vaccine Immunol. 2007;14(9):1245-8.

14. Ministry of Social Development, Permanent Secretary (AI). Letter to: Federico Costa (Centro de Pesquisa Gonçalo Moniz, Bahia, BR). 2007 April 25. The Valley, Anguilla: MSD; 2007.

15. Government Information Service (BB). Leptospirosis warning [press release]. 2006 June 24. St. Michael, Barbados: GIS; 2006.

16. Government Information Service (BB). Leptospirosis warning from the Ministry of Health [press release]. 2005 June 28. St. Michael, Barbados: GIS; 2005.

17. Dirección Nacional de Estadística (CU). Estadísticas de salud. Series de tiempo de morbilidad. Casos notificados por leptospirosis según grupos de edad: Cuba 1978-2005. Havana: DNE; 2006. Available from: http:// www.sld.cu/galerias/doc/sitios/dne/ leptospirosis_1970-2005.doc Accessed 22 August 2007.

18. Secretaria de Estado de Salud Pública y Asistencia Social, Dirección General de Epidemiología (DO). Análisis de situación de salud. Indicadores básicos 2003. Morbilidad registrada según provincia 2002. Santo Domingo: SESPAS; 2003. Available from: http://www. sespasdigepi.gob.do/ Accessed 22 August 2007.

19. Secretaria de Estado de Salud Pública y Asistencia Social, Dirección de Epidemiología (DO). Análisis de situación de salud. Indicadores básicos 2002. Morbilidad registrada según provincia 2001. Santo Domingo: SESPAS; 2002. Available from: http://www.sespasdigepi. gob.do/ Accessed 22 August 2007.

20. Secretaria de Estado de Salud Pública y Asistencia Social, Dirección General de Epidemiología (DO). Análisis de situacion de salud de la Republica Dominicana 2003. Santo Domingo: SESPAS; 2003. 124 pp. Available from: http:/ / www.arssenasa.gov.do/index/ documentos/Analisis_Situacion_Salud_2003. pdf Accessed 22 August 2007.

21. Institut Pasteur (FR). Contribution à la surveillance de la leptospirose en France en 1996 [Internet]. Paris: IP; 1996. Available from: http:/ / www.pasteur.fr/ recherche/Leptospira / textcnr1996.html Accessed 22 August 2007.

22. Institut Pasteur (FR). Contribution à la surveillance de la leptospirose en France en 1997 [Internet]. Paris: IP; 1997. Available from: http:/ /
www.pasteur.fr/recherche/Leptospira / textcnr1997.html Accessed 22 August 2007.

23. Institut Pasteur (FR). Contribution à la surveillance de la leptospirose en France en 1998 [Internet]. Paris: IP; 1998. Available from: http:/ / www.pasteur.fr/recherche/Leptospira/ textcnr1998.html Accessed 22 August 2007.

24. Institut Pasteur (FR). Contribution à la surveillance de la leptospirose en France en 1999 [Internet]. Paris: IP; 1999. Available from: http:/ / www.pasteur.fr/recherche/Leptospira/ textcnr99.html Accessed 22 August 2007.

25. Institut Pasteur (FR) Contribution à la surveillance de la leptospirose en France en 2000 [Internet]. Paris: IP; 2000. Available from: http:/ / www.pasteur.fr/recherche/Leptospira/ textcnr00.html Accessed 22 August 2007.

26. Institut Pasteur (FR). Rapport d'activite du Centre de Reference des leptospires pour l'annee 2001 [Internet]. Paris: IP; 2001. Available from: http://www.pasteur.fr/recherche/ Leptospira/textcnr01.html Accessed 22 August 2007

27. Institut Pasteur (FR). Rapport d'activite du Centre de Reference des leptospires pour l'annee 2002 [Internet]. Paris: IP; 2002. Available from: http://www.pasteur.fr/recherche/ Leptospira/textcnr02.html Accessed $22 \mathrm{Au}-$ gust 2007.

28. Institut Pasteur (FR). Contribution à la surveillance de la leptospirose en France en 2003 [Internet]. Paris: IP; 2003. Available from: http:// www.pasteur.fr/recherche/Leptospira / textcnr03.html Accessed 22 August 2007.

29. Institut Pasteur (FR). Contribution à la surveillance de la leptospirose en France en 2004 [Internet]. Paris: IP; 2004. Available from: http:/ / www.pasteur.fr/recherche/Leptospira/ textcnr04.html Accessed 22 August 2007

30. Institut Pasteur (FR). Contribution à la surveillance de la leptospirose en France en 2005 [Internet]. Paris: IP; 2005. Available from: http:/ / www.pasteur.fr/recherche/Leptospira/ textcnr05.html Accessed 22 August 2007.

31. Ministry of Health, Government Statistics Department (LC). Reported cases of communicable/notifiable diseases [Internet]. Castries: GSD; 2004. Available from: http://www. stats.gov.lc Accessed 1 February 2007.

32. Ministry of Health, Wellness \& the Environment, Medical \& Health Care, Health Promotion (VC). Leptospirosis in St. Vincent and the Grenadines [Internet]. Kingstown: MHE; 2007. Available from: http://www.health.gov. $\mathrm{vc} /$ index.php?option $=$ com_content\&view = article\&id=12\&Itemid=13 Accessed $22 \mathrm{Au}-$ gust 2007

33. Ministerio de Salud (CR). Memoria anual 2005: 4 años de gestión. San José: MS; 2006. Pp. 75-126. Available from: http://www.lib. utexas.edu/benson/lagovdocs/costarica/ federal/salud/mem2005.pdf Accessed 22 August 2007.

34. Ministerio de Salud, Sistema Nacional de Vigilancia de la Salud (CR). Eventos prioritarios de salud de notificación obligatoria en Costa Rica 2002-2003. Bol Epidemiol (Costa Rica). 2003;3(31):1-2. Available from: http:// www.ministeriodesalud.go.cr/index.php/ inicio-vigilancia-salud-boletines-ms / doc download/537-boletin-vigilancia-de-la-saludsemana-31-de-2003 Accessed 22 August 2007.

35. Pan American Health Organization. Regional Core Health Data System. Country health profile: El Salvador [Internet]. Washington PAHO; 2002. Available from: http://www. paho.org/English/DD/AIS/cp_222.htm Accessed 22 August 2007.

36. Asamblea Legislativa de la Republica de El Salvador. Decreto $N^{\circ} 955$ de 11 de mayo de 1988. Leyes relativas al sistema de salud de El Salvador: enfermedades de declaración obligatoria. Diario Oficial. 1988;86(t. 299; Sec.21; Art. 131):32. Available from: http://www.disasterinfo.net/PED-Sudamerica / leyes / leyes / centroamerica/salvador/salud/Codigo_de_ Salud.pdf Accessed 22 August 2007.

37. Ministerio de Salud Pública (GT). Situación de los principales eventos de vigilancia epidemiológica. Semana Epidemiol Guatemala. 2006;8(426):1-8. Available from: http:/ / epidemiologia.mspas.gob.gt/semanas/2006/ SEM\%20No\%2012-2006.pdf Accessed 22 August 2007.

38. Ministerio de Salud Pública (GT). Situación de los principales eventos de vigilancia epidemiológia. Semana Epidemiol Guatemala. 2005;7(414):1-4. Available from: http:// epidemiologia.mspas.gob.gt/semanas/2005/ SEM\%20No\%2052-2005.pdf Accessed 22 August 2007.

39. Ministerio de Salud Pública, Dirección General del Sistema Integral de Atención en Salud (GT). Bol Epidemiol (Guatemala). 2004:7(342):1-9.

40. Ministerio de Salud (NI). Situación epidemiológica de la leptospirosis en Nicaragua. Bol Epidemiol (Nicaragua). 2005;(41):1-4 Available from: https://minsa.gob.ni/index. php?option $=$ com remository\&Itemid $=52 \&$ fun c=fileinfo\&id=6197 Accessed 22 August 2007.

41. Ministerio de Salud, Departamento de Vigilancia de Factores Protectores y de Riesgo a la Salud y Enfermedades (PA). Casos de enfermedades transmisibles notificadas. Bol Epidemiol (Panama). 2000;24(9-12):1-12. Available from: http://www.minsa.gob.pa/minsa/tl files/documents/informacion_salud/epidemiologia/boletines/2000/VOL XXIV 9\%20\%2012_2000.pdf Accessed 22 August 2007.

42. Ministerio de Salud, Departamento de Vigilancia de Factores Protectores y de Riesgo a la Salud y Enfermedades (PA). Casos de enfermedades transmisibles notificadas. Bol Epidemiol (Panama). 2001;25(10-12):1-10. Available from: http://www.minsa.gob.pa/ minsa/tl_files/documents / informacion salud / epidemiologia / boletines / 2001/ VOL\%20XXV\%2010\%20-\%2012_2001.pdf Accessed 22 August 2007.

43. Ministerio de Salud, Departamento de Vigilancia de Factores Protectores y de Riesgo a la Salud y Enfermedades (PA). Casos de enfermedades transmisibles notificadas. Bol Epidemiol (Panama). 2002. Available from: http:/ / www.minsa.gob.pa/minsa/tl_files/ documents/informacion salud/epidemio logia/boletines/2002/BOLETINES_2002.pdf Accessed 22 August 2007

44. Secretaria de Salud, Dirección General de Epidemiología (MX). Enfermedades zoonoticas. Cuadro 8: casos por entidad federativa de enfermedades zoonóticas hasta la semana epidemiológica 50; rabia hasta la 52 del 2001. Vigil Epidemiol (Mexico). 2001;(52). Available from: http:/ /www.dgepi.salud.gob.mx boletin/2001/sem52/cua8.pdf Accessed 1 February 2007 
45. Secretaria de Salud, Dirección General de Epidemiología (MX). Enfermedades zoonoticas. Cuadro 8: casos por entidad federativa de enfermedades zoonóticas hasta la semana epidemiológica 50; rabia hasta la 52 del 2002. Vigil Epidemiol (Mexico). 2002;(52). Available from: http:/ / www.dgepi.salud.gob.mx/ boletin/2002/sem52/cua8.pdf Accessed 1 February 2007.

46. Secretaria de Salud, Dirección General de Epidemiología (MX). Enfermedades zoonoticas. Cuadro 8: casos por entidad federativa de enfermedades zoonóticas hasta la semana epidemiológica 51; rabia y fiebre del Oeste del Nilo hasta la 53 del 2003. Vigil Epidemiol (Mexico). 2003;(53). Available from: http://www.dgepi. salud.gob.mx/boletin/2003/sem53/pdf / cua8.pdf Accessed 1 February 2007.

47. Secretaria de Salud, Dirección General de Epidemiología (MX). Enfermedades zoonoticas. Cuadro 8: casos por entidad federativa de enfermedades zoonóticas hasta la semana epidemiológica 50; rabia y fiebre del Oeste del Nilo hasta la 52 del 2004. Vigil Epidemiol (Mexico). 2004;(52). Available from: http://www.dgepi. salud.gob.mx/boletin/2004/sem52/pdf/ cua8.pdf Accessed 1 February 2007.

48. Secretaria de Salud, Dirección General de Epidemiología (MX). Enfermedades zoonoticas. Cuadro 8: casos por entidad federativa de enfermedades zoonóticas hasta la semana epidemiológica 51; rabia y fiebre del Oeste del Nilo hasta la 52 del 2005. Vigil Epidemiol (Mexico). 2005;(52). Available from: http://www.dgepi. salud.gob.mx/boletin/2005/sem52/pdf/ cua8.pdf Accessed 1 February 2007.

49. Secretaria de Salud, Dirección General de Epidemiología (MX). Enfermedades zoonoticas. Cuadro 8: casos por entidad federativa de enfermedades zoonóticas hasta la semana epidemiológica 51; rabia y fiebre del Oeste del Nilo hasta la 52 del 2006. Vigil Epidemiol (Mexico). 2006;(52). Available from: http://www.dgepi. salud.gob.mx/boletin/2006/sem52/pdf / cua8.pdf Accessed 1 February 2007.

50. Ministerio de Salud y de Ambiente de la Nación (AR). Patologías de notificación obligatoria. Bol Epidemiol Period (Argentina). 2004;2(16):13. Available from: http://msal. gov.ar/htm/site/sala_situacion/PANELES/ boletines/boletin_16-2004.pdf Accessed 22 August 2007.

51. Ministerio de Salud y de Ambiente de la Nación (AR). Patologías de notificación obligatoria. Bol Epidemiol Period (Argentina). 2005;4(28):13. Available from: http://msal. gov.ar/htm/site/sala_situacion/PANELES/ boletines/boletin_28-2005.pdf Accessed 22 August 2007.

52. Ministerio de Salud y de Ambiente de la Nación, Dirección de Epidemiología (AR). Notificaciones recibidas al 29 de Abril de 2003. Bol Sem Notific (Argentina). 2003;(52):7. Available from: http://msal.gov.ar/htm/ site/sala_situacion/PANELES/boletines/02_ Bonr53.xls Accessed 22 August 2007.

53. Ministerio de Salud y de Ambiente de la Nación, Dirección de Epidemiología, Centro de Información (AR). Leptospirosis denunciada al Sistema de Vigilancia Epidemiológica-SINAVE. Letter to: Federico Costa (Centro de Pesquisa Gonçalo Moniz, Bahia, BR). 2007 Feb 22. Buenos Aires: MSAL; 2007.
54. Senado y Cámara de Diputados de la Nación Argentina. Ley no. 15.465. de 29 de septiembre de 1960. Bol Oficial (Argentina). 1960;68(19369):2. Available from: http:// www.boletinoficial.gov.ar/DisplayPdf. aspx?s=BPBCF\&f=19601028 Accessed $22 \mathrm{Au}-$ gust 2007.

55. Ministerio de Salud y Deportes (BO). Sistema Nacional de Información en Salud. Situación epidemiológica relevante. Bol Sem Vigil (Bolivia). 2001;(7).

56. Ministério da Saúde (BR). Vigilância epidemiológica de doenças transmissíveis. Série histórica de casos e óbitos de doenças de notificação compulsória-Brasil, 1980 a 2005. Brasília: MS; 2006. Available from: http:// portal.saude.gov.br/portal/arquivos/pdf/ planilhas_dnc_casos_e_obitos_todas_2006. pdf Accessed 17 July 2010.

57. Ribeiro AF. Leptospirose, avaliação de fatores prognósticos da doença, município de São Paulo, 2005. Bol Epidemiol Paul. 2006;3(28): 2-8.

58. Ministerio de Salud, Departamento de Epidemiología (CL). Situación nacional de las enfermedades de notifiación obligatoria (19982005). Bol Electr Mensual Vigil Epidemiol (Chile). 2006;(40). Available from: http:/ / epi. minsal.cl/evigant/Numero40/evigia/index. html Accessed 22 August 2007.

59. Ministerio de Salud, Departamento de Epidemiología (CL). Situación de las enfermedades de notifiación obligatoria (ene-jun/jul. 2003). Bol Electr Mensual Vigil Epidemiol (Chile). 2003;(20). Available from: http://epi.minsal. cl/evigant/Numero20/evigia/ Accessed 22 August 2007.

60. Ochoa JE, Sánchez A, Ruíz I. Epidemiología de la leptospirosis en una zona andina de producción pecuaria. Rev Panam Salud Publica. 2000;7(5):325-31.

61. Ministerio de Salud, Sistema Nacional de Vigilancia en Salud Pública, Oficina de Epidemiología (CO). Situación actual de la leptospirosis en el país. Semana Epidemiol (Colombia). 2000;(13):1-6. Available from: http://www. col.ops-oms.org/sivigila/IndiceBoletines 2000.asp Accessed 22 August 2007.

62. Ministerio de Salud Pública (EC). Vigilancia epidemiológica. Número de casos y tasas de incidencia anual de leptospirosis. Quito: MSP; 2007.

63. Ministerio de Salud Pública (EC). Formulario EP-2. Enfermedades y eventos de notificación obligatoria sujetas a vigilancia epidemiológica. Anuario 2005. Quito: MSP; 2005.

64. Organización Panamericana dela Salud. Informe de la 4a. Reunión de la Red de Vigilancia para las Enfermedades Emergentes y Reemergentes de la Región Amazónica, 15-18 marzo 2003, Belém, Pará, Brasil. (OPS/DPC/CD/248/03). Available from: http://www.paho.org/common/Display.asp?Lang=S\&RecID=6545 Accessed 22 August 2007.

65. Ministerio de Salud, Oficina General de Epidemiología (PE). Bol epidemiol (Peru). 2005; 14(37):1-12. Available from: http://www. dge.gob.pe/boletines/2005/37.pdf Accessed 22 August 2007.

66. Organización Panamericana de la Salud. Informe de Paises: Uruguay. 2a. Reunión Conjunta de la Red de Vigilancia para Enfermedades Emergentes en el Amazonas y la Región de Cono Sur, 23-24 marzo 2002, Atlanta, Geor- gia, USA. (OPS/HCP/HCT/211/02). Available from: http://www.paho.org/Spanish/ $\mathrm{AD} / \mathrm{DPC} / \mathrm{CD} /$ Redes-eer-Atlanta2002-13furu.pdf Accessed 22 August 2007.

67. Universidad de la República, Facultad de Medicina, Instituto de Higiene (UY). Departamento de Medicina Preventiva y Social: teóricos [Internet]. Montevideo: UR; 2007. Available from: http://higiene.edu.uy/ Accessed 22 August 2007.

68. Ministerio de Salud Pública, Departamento de Epidemiología, Vigilancia en Salud Pública (UY). Enfermedades de notificación obligatoria: casos notificados confirmados hasta la semana epidemiológica 52 [Internet]. Montevideo: MSP: 2006. Available from: www. msp.gub.uy/andocasociado.aspx?6489,22917 Accessed 22 August 2007.

69. Organización Panamericana de la Salud; Ministerio de Salud, Dirección de Vigilancia Epidemiológica (VE). Vigilancia y control de enfermedades gráficos y mapas: leptospirosis. Casos confirmados de leptospirosis por estados Venezuela 1996, 1997 y 1998. Caracas: MS; 1999.

70. Ministerio de Salud, Dirección de Epidemiología y Análisis Estratégico, Dirección de Vigilancia Epidemiológica (VE). Bol Epidemiol Sem (Venezuela). 2006;55(50):1-18. Available from: http://www.mpps.gob.ve/ index.php?option $=$ com_phocadownload\& view=category \&download $=144$ : boletin-no50\&id=5:2006 Accessed 22 August 2007.

71. Ministerio de Salud, Dirección de Epidemiología y Análisis Estratégico, Dirección de Vigilancia Epidemiológica (VE). Bol Epidemiol Sem (Venezeula). 2005;54(52):1-20. Available from: http:/ / vitae.ucv.ve/images/ user/VITAE\%2026/Alerta52.pdf Accessed 22 August 2007.

72. Caribbean Epidemiology Centre. Report on communicable diseases, weeks 1-12, 2006. CAREC Surveill Rep. 2006;26(2):1-23. Available from: http://www.mainlib.uwi.tt/ divisions / wi / collmain / archives / carec/ csrjune 2006.pdf Accessed 22 August 2007.

73. World Organisation for Animal Health. Handistatus II: zoonoses (human cases): global cases of leptospirosis from 1996 to 2004 [Internet]. Paris: OIE; 2004. Available from: http:/ / web.oie.int/hs2/gi_zoon_mald. asp?c_cont $=2 \& c \_$mald $=24 \&$ annee $=2004$ Accessed 22 August 2007.

74. Pan American Health Organization. Regional Core Health Data System. Country health profile:Barbados. Washington:PAHO;2001.Available from: http://www.paho.org/english/ sha/prflbar.htm Accessed 22 August 2007.

75. Pan American Health Organization. Regional Core Health Data System. Country health profile: Dominican Republic. Washington: PAHO; 2001. Available from: http://www. paho.org/english/sha/prfldor.htm Accessed 22 August 2007.

76. Pan American Health Organization. Regional Core Health Data System. Country health profile: Guatemala. Washington: PAHO; 2002. Available from: http://www.paho.org/ english/sha/prflgut.htm Accessed 22 August 2007.

77. International Leptospirosis Society. ILS worldwide survey 1998, 1999, 2000 [PowerPoint presentation]. Geneva: World Health Organization/ILS; 2002. Available from: http:// 
www.leptonet.net/html/ils_worldwide_ survey.asp

78. Organización Panamericana de la Salud. Perfiles de país. Bol Epidemiol. 2003;24(1):6-24. Available from: http://www.paho.org/ spanish/dd/ais/EB v24n1.pdf Accessed 22 August 2007.

79. Pan American Health Organization. Health in the Americas: Suriname. Washington: PAHO; 1998. Pp. 470-83. Available from: http:// www.paho.org/english/HIA1998/Suriname. pdf Accessed 22 August 2007.

80. Caribbean Epidemiology Centre. Report on communicable diseases for weeks 13-36, 2006. CAREC Surveill Rep. 2006;26(3):8-24. Available from: http://mainlib.uwi.tt/divisions/ wi/collmain/archives/carec/csroctober2006. pdf Accessed 22 August 2007.

81. Ministerio de Salud, Dirección Vigilancia de la Salud, Unidad de Información Estadística (CR). Mortalidad por enfermedades de declaración obligatoria en Costa Rica: año 2005. San José: Organización Panamericana de la Salud; 2006. Pp. 1-49. Available from: http:// www.binasss.sa.cr/mortalidad2005.pdf Accessed 22 August 2007.

82. Ministerio de Salud (NI). Enfermedades sujetas a vigilancia epidemiológica. Bol Epidemiol (Nicaragua). 2003;(52):1-9.

83. Ministerio de Salud (NI). Enfermedades sujetas a vigilancia epidemiológica. Bol Epidemiol (Nicaragua). 2004;(52):1-9.

84. Ministerio de Salud (NI). Enfermedades sujetas a vigilancia epidemiológica. Bol Epidemiol (Nicaragua). 2005;(52):1-9. Available from: http:// www.minsa.gob.ni/index.php?option=com remository \&Itemid $=52 \&$ func $=$ startdown \&id=6258 Accessed 22 August 2007.

85. Ministerio de Salud (NI). Enfermedades sujetas a vigilancia epidemiológica. Bol Epidemiol (Nicaragua). 2006;(52):1-9. Available from: http://www.minsa.gob.ni/index.php? option $=$ com_remository\&Itemid $=52 \&$ func $=$ fileinfo\&id=6324 Accessed 22 August 2007

86. Ministerio de Salud y de Ambiente de la Nación, Dirección de Estadísticas e Información de Salud (AR). Cantidad de defunciones por leptospirosis, por provincia de residencia y grupo de edad. República Argentina, años 1996-2005. Letter to: Federico Costa (Centro de Pesquisa Gonçalo Moniz, Bahia, BR). 2007 Febr 22. Buenos Aires: DEIS/MS; 2007.

87. Ministerio de Salud, Departamento de Epidemiología (CL). Situación del antrax, brucelosis, triquinosis, leptospirosis, hidatidosis y enfermedad de chagas [Internet]. Bol Electr Mensual Vigil Epidemiol (Chile). 2006;(42). Available from: http://epi.minsal.cl/evigant/ Numero42/evigia/ Accessed 22 August 2007.

88. McBride AJ, Athanazio DA, Reis MG, Ko AI. Leptospirosis. Curr Opin Infect Dis. 2005; 18(5):376-86.

89. Ko AI, Galvão Reis M, Ribeiro Dourado CM, Johnson WD Jr, Riley LW. Urban epidemic of severe leptospirosis in Brazil. Salvador Leptospirosis Study Group. Lancet. 1999;354(9181): $820-5$.

90. Segura ER, Ganoza CA, Campos K, Ricaldi JN, Torres S, Silva H, et al. Clinical spectrum of pulmonary involvement in leptospirosis in a region of endemicity, with quantification of leptospiral burden. Clin Infect Dis. 2005;40(3):343-51.

91. Cumberland P, Everard CO, Levett PN. Assessment of the efficacy of an IgM-elisa and microcopic agglutination test (MAT) in the diagnosis of acute leptospirosis. Am J Trop Med Hyg. 1999;61(5):731-4.

92. Lhomme V, Grolier-Bois L, Jouannelle J, Elisabeth L. Leptospirose en Martinique de 1987 à 1992: bilan d'une étude épidémiologique, clinique et biologique. Med Mal Infect. 1996; 26(2):94-8.

93. Pila Pérez R, Roura Carrasco J, Pila Peláez R, Caveda Estela O, Torres Vadella GS, García Peña J. Estudio clínico de la leptospirosis humana: a propósito de 400 casos consecutivos. Mapfre Med. 1996;7(1):60-5

94. Dupont H, Dupont-Perdrizet D, Perie JL, Zehner-Hansen S, Jarrige B, Daijardin JB. Leptospirosis: prognostic factors associated with mortality. Clin Infect Dis. 1997;25(3):720-4.

95. Lau CL, Smythe LD, Craig SB, Weinstein P. Climate change, flooding, urbanisation and leptospirosis: fuelling the fire? Trans R Soc Trop Med Hyg. 2010;104(10):631-8.

96. Sarkar U, Nascimento SF, Barbosa R, Martins R, Nuevo H, Kalofonos I, et al. Populationbased case-control investigation of risk factors for leptospirosis during an urban epidemic. Am J Trop Med Hyg. 2002;66(5):605-10.

Manuscript received on 28 December 2011. Revised version accepted for publication on 26 May 2012.

RESUMEN Objetivo. Determinar los procedimientos actuales de notificación de la leptospirosis en la Región de las Américas.

Métodos. Se recopiló información de los sitios web oficiales de los ministerios de

Vigilancia de la leptospirosis
en la Región de las Américas,
de 1996 al 2005:
análisis de los datos de
los ministerios de salud
salud de los países de la Región de las Américas y dos organizaciones internacionales, de comunicaciones personales y de tres bases de datos internacionales de morbilidad. Con la excepción de las bases de datos de morbilidad, el análisis se limitó a los informes oficiales que citaban casos de leptospirosis, clínicamente presuntos o confirmados por el laboratorio o defunciones por esta infección, ocurridos durante el período de 1996 al 2005.

Resultados. Un total de 73 informes de los 1644 considerados reunían los criterios de selección y se incluyeron en el análisis. Se dispuso de datos publicados sobre leptospirosis de la mitad de los países o territorios soberanos ( 24 de 48), 18 de los cuales contaban con políticas de notificación obligatoria de la leptospirosis. La suma de las medianas del número de casos de leptospirosis notificados anualmente por los 24 países o territorios fue de 4713,5 , pero tres países en particular (Brasil, Costa Rica y Cuba) representaban 83,1\% (3 920 casos) de las notificaciones. Ocho países $(16,7 \%$ ) notificaron defunciones debidas a leptospirosis. La suma de las medianas del número de defunciones notificadas anualmente por los ocho países fue de 380, pero $349(91,8 \%)$ fueron notificadas por Brasil.

Conclusiones. Los procedimientos de notificación de la leptospirosis en la Región de las Américas son limitados. Por consiguiente, los números de casos y muertes notificados no son representativos de la Región. La carencia de datos de leptospirosis de muchos países o territorios puede reflejar los puntos débiles de ciertos aspectos de los sistemas nacionales de vigilancia, incluidas las políticas de notificación obligatoria, la infraestructura de laboratorios clínicos para confirmar los casos y la capacidad para recopilar los casos notificados. Es necesario mejorar la vigilancia de los casos y las defunciones por leptospirosis en la Región de las Américas con objeto de permitir el seguimiento de los perfiles epidemiológicos regionales y calcular la carga de esta importante enfermedad.

Palabras clave Leptospirosis; vigilancia epidemiológica; notificación de enfermedad; revisión; Américas. 